\title{
NIEUDANA WYPRAWA LISIOGÓRSKA \\ JAKO PRÓBA RUCHU POWSTAŃCZEGO W 1846 ROKU \\ NA TERENIE MIASTA TARNOWA I OKOLIC W ŚWIETLE WSPOMNIEŃ FRANCISZKA WiESIOŁOWSKIEgo
}

\section{Stawomir Piskozub}

Rok 1846 mógł okazać się niezwykle istotny zarówno dla Galicji, jak i dla ziem pozostałych zaborów. Po nieudanym powstaniu listopadowym polska konspiracja zorganizowała się na tyle, że postanowiła wprowadzić w życie kolejny plan rewolucyjny, którego ogniskiem miały być początkowo Galicja wraz z Wolnym Miastem Krakowem i Poznańskie. Z nich ruch miał się rozprzestrzenić na dalsze ziemie, by w efekcie przyczynić się do uzyskania upragnionej niepodległości. Ostatecznie czas ten zapisał się na stałe w historii Polski - istniejącej wówczas, ze względu na okres zaborów, jedynie w sercach rodaków. Trudno uznać jednak ten ruch jako wydarzenie, które zapisało się złotymi zgłoskami, bowiem w jego efekcie doszło do niezwykle negatywnych reperkusji, które szczególnie boleśnie dotknęły tereny Małopolski. Mowa tu o wydarzeniach, które przeszły do historii pod nazwą rabacji (rzezi) galicyjskiej. To wystąpienie chłopskie obejmujące tereny Galicji Zachodniej o charakterze antyszlacheckim i antypańszczyźnianym. Napady na dwory rozpoczęły się 19 lutego, a zatem bezpośrednio po nieudanej próbie wzniecenia powstania w okolicach Tarnowa. Choć ataki dotknęły również cyrkuły: bocheński, sądecki, wielicki i jasielski, to jednak miejscem, gdzie dokonano największych łupiestw, był cyrkuł tarnowski. Czy próba przejęcia władzy przez szlachtę jeszcze bardziej rozjuszyła chłopów? Niewątpliwie warto lepiej przyjrzeć się poczynaniom niedoszłych powstańców z Tarnowa i jego okolic. Wnikliwsza 
analiza zrywu szlacheckiego w Tarnowskiem dopełnia obraz powstania krakowskiego. Dotąd historycy skupiali się przede wszystkim na ruchach, jakie miały miejsce $\mathrm{w}$ Krakowie, oraz wystąpieniach chłopskich, podczas gdy wydarzenia z Tarnowa i okolic uznać można za nie mniej istotne.

Podczas analizy literatury dotyczącej wydarzeń z 1846 r. zauważalna jest wielość opracowań wydanych w drugiej połowie XIX i pierwszej połowie XX w. Pozycje te, choć przydatne, nierzadko pozbawione są obiektywizmu oraz stosownego aparatu naukowego, co sprawia, że poddając je wnikliwej analizie, należy uczynić to z odpowiednim dystansem ${ }^{1}$. Druga grupa to opracowania głównie z lat 50. i 60., wśród których dominują książki takich naukowców jak Stefan Kieniewicz, Marian Żychowski, Jerzy E. Płomieński, Władysław Bortnowski, Czesław Wycech czy Wojciech Bartel ${ }^{2}$. To wartościowe pozycje przedstawiające ogólny obraz wydarzeń, $\mathrm{w}$ których $\mathrm{z}$ racji kilkudziesięciu lat od ich ukazania się brakuje świeżego poglądu na sprawę. Należy bowiem uwzględnić okres, w którym powstały, co sprawia, że nie brak w nich pewnej stronniczości charakterystycznej dla ich czasów. Pomiędzy pozycjami ze wspomnianego okresu a tymi z XXI w. warto odnotować jedynie zbiór studiów opracowany przez Michała Śliwę̧, prace Mariana Tyrowicza ${ }^{4}$ oraz książkę Krystyny Poklewskiej ${ }^{5}$ stanowiącą przegląd literatury pięknej i naukowej dotyczącej wydarzeń z 1846 r. Ostatnimi czasy wyszło kilka pozycji poruszających tematykę analizowanych wydarzeń. Sporym zainteresowanie cieszy się osoba Jakuba Szeli, a więc jednej z najbardziej znanych

$1 \quad$ Zob. S. De mb iński, Rok 1846. Kronika dworów szlacheckich zebrana na pięćdziesięcioletnia rocznicę smutnych wypadków lutego, Jasło 1896; W. Michna, Pamiętniki naocznego świadka $z$ r. 1846, „Kalendarz Ilustrowany Wieńca i Pszczółki: pisemek politycznych ludowych na rok pański 1880”; K. Ostaszewski - B arański, Krwawy rok. Opowiadanie historyczne, Złoczów 1897; A. Tessarczyk, Rzeź galicyjska 1846r., czyli szczegółowy opis dokonanych morderstw, rozbojów i łupieztw, wraz $z$ ważniejszymi wypadkami, jakie tym okropnym scenom towarzyszyly w zwiazku $z$ intrygami biurokracyi, Kraków 1848. Wymienione pozycje to przykład najbardziej subiektywnych dzieł niepozbawionych emocji i stronniczości. Stanowią doskonałą skarbnicę wiedzy, jeżeli spojrzy się na nie pod kątem analizy psychologicznej stanu szlacheckiego.

2 Zob. S. Kieniewicz, Ruch chłopski w Galicji w 1846 roku, Wrocław 1951; M. Żychowski, Rok 1846 w Rzeczypospolitej Krakowskiej i Galicji, Warszawa 1956; J.E. Pło mi eński, W kręgu polskiej irredenty: (o Edwardzie Dembowskim, Jakubie Szeli i rzezi galicyjskiej), Warszawa 1946; W. B ort nowski, O powstaniu krakowskim 1846, Warszawa 1950; C. Wycech, Powstanie chłopów w 1846 r. Jakub Szela, Warszawa 1955; W. M. B artel, Rewolucja krakowska 1846 roku na tle niektórych polskich koncepcyj społeczno-politycznych lat 1831-1846, Warszawa 1957.

3 Zob.; Rok 1846 w Galicji. Ludzie, wydarzenia, tradycje, oprac. M. Śliwa, Kraków 1997.

4 M. Tyrowicz, Wolne miasto Kraków w ogniu walk społecznych 1815-1846, Kraków 1955; i d e m, Jan Tyssowski i rewolucja 1846 r. w Krakowie. Dzieje porywu i pokuty, Kraków 1986.

5 Zob. K. Poklewska, Krew na śniegu. Rzecz o rabacji galicyjskiej w literaturze polskiej, Wrocław 1986. 
postaci z omawianego okresu. Postać w XIX w. stanowczo potępiana w wyniku świeżego podejścia do sprawy obecnie bardziej przedstawiana jest jako tragiczna ${ }^{6}$. Szczególnie istotnym, a przede wszystkim świeżym spojrzeniem na sprawę rabacji galicyjskiej są książka autorstwa Michała Montowskiego ${ }^{7}$ oraz zbiorowa praca Krzysztofa Daszyka, Tomasza Szuberta i Tomasza Kargola ${ }^{8}$ - najmłodsze ze wspominanych opracowań. Ich niewątpliwą zaletą jest fakt, że ukazują sytuację w szerszym kontekście, obszernie przedstawiając problemy poszczególnych grup społecznych i wzajemny brak zrozumienia.

Odrębną część stanowią pamiętniki i dzienniki sporządzone przez naocznych świadków oraz zbiory źródeł dotyczących wydarzeń z 1846 r. ${ }^{9}$ Część z nich została wydana jeszcze w XIX w., z kolei pozostałe doczekały się opracowania i dodatkowej analizy, dzięki czemu można zweryfikować pewne nieścisłości i wytknąć błędy w relacjach autorów wspomnień ${ }^{10}$.

Jedną z głównych postaci opisywanych wydarzeń, a więc próby wzniecenia powstania na terenach Galicji Zachodniej, był szlachcic Franciszek Wiesiołowski, wyznaczony na powstańczego wielkorządcę Galicji ${ }^{11}$. Dzięki jego osobistym wspomnieniom spisanym na kartach pamiętnika ${ }^{12}$ można dowiedzieć się więcej

6 Zob. S. Białas, Jakub Szela. Kim był?, Kraków 2006; K. Tra ciło w ski, Jakub Szela, Warszawa 2011; T. Szu ber t, Jak(ó)b Szela. (14) 15 lipca 1787-21 kwietnia 1860, Warszawa 2014.

7 Zob. M. Mon towski, Krew, która woła. Pamięć i niepamięć o rzezi galicyjskiej 1846, Kraków 2016.

8 Zob. Rok 1846 w Krakowie i Galicji, red. K.K. D a szyk, T. Kargol, T. Szub e rt, Kraków 2016.

9 Zob. Rewolucja polska 1846 roku. Wybór źródeł, oprac. S. Ki eniewicz, Wrocław 1950; Rok 1846 w Galicji. Materiały źródłowe, oprac. J. Si e r a d zki, C. Wy ce ch, Warszawa 1958.

10 Zob. Rabacja na Powiślu. Dziennik Marianny Pikuzińskiej i relacje chłopskie o krwawych wydarzeniach 1846 r., oprac. K. B ánburski, W. Konieczny, Tarnów 2006. Dziennik wydany przez Muzeum Okręgowe w Tarnowie jest obecnie najnowszym opracowanym dziennikiem z czasów rabacji galicyjskiej opisującym wydarzenia z cyrkułu bocheńskiego.

11 Franciszek Wiesiołowski (1814-1868) - szlachcic wywodzący się ze średnio majętnej rodziny, stopniowo pnący się po szczeblach ruchu konspiracyjnego, by w latach 1845-46 stać się czołową postacią konspiracji galicyjskiej. Autor Ustępu z moich wspomnień oraz Pamiętnika z r. 1845-46, stanowiących źródło do wydarzeń z okresu jego działalności konspiracyjnej.

12 Zob. F. Wiesiołow ski, Pamiętnik z r. 1845-46, Lwów 1868. Pośmiertnie wydany Pamiętnik opisujący lata 1845-1848 i przedstawia okres przygotowania do powstania i próbę nieudanego zrywu niepodległościowego aż do stopniowego zmierzchu działalności autora wspomnień. To najważniejszy i najburzliwszy okres życia ostatniego dziedzica Wojsławia. W pamiętniku przedstawione są przede wszystkim przygotowania do nieudanego powstania w Galicji - ukazane z perspektywy głównego koordynatora działań wskazują, z jakimi problemami musieli borykać się powstańcy. Praca stanowi także dobry materiał do analizy ich działań czy dostrzeżenia błędów organizacyjnych. Wspomniane dzieła (zważając, że jako subiektywne relacje mogą nierzadko pomijać ważniejsze wydarzenia bądź w pewien sposób przeinaczać fakty) w analizie i porównaniu $\mathrm{z}$ innymi pamiętnikami bądź opracowaniami historycznymi, od najstarszych po te najaktualniejsze, pomagają zobrazować wspomniane działania, obiektywizując tym samym relacje Wiesiołowskiego. 


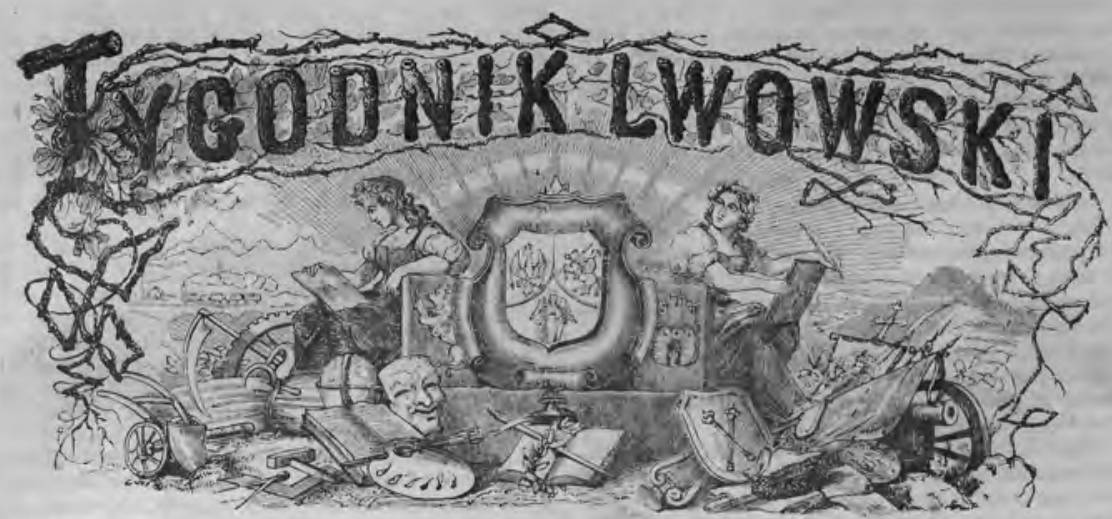

Rok II.

1808.

\begin{tabular}{|c|c|c|}
\hline 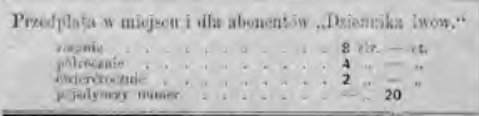 & $\begin{array}{l}\text { Ny. } 21 . \\
\text { 15. Caerwea. }\end{array}$ & 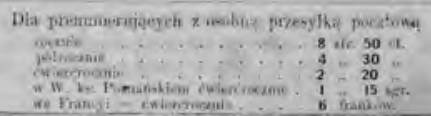 \\
\hline
\end{tabular}

\section{Fr. Wiesielewski.}

Concin deicjos basodo na-

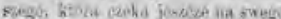

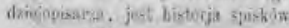
po mant $1 \times 31$.

Materialow i paningaikow ma-

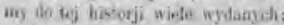
wigerg jescos niesylangoln maj-

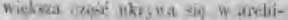

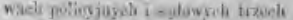
rediaciced rayfiw.

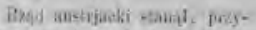

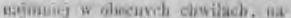

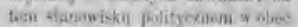

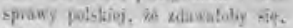

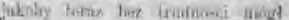

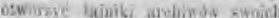
dengepisesomi,

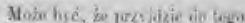

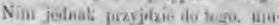

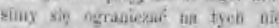

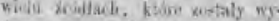

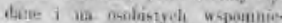

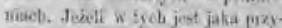

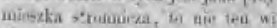

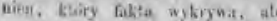
toist kbing jo ithrowa.

Jednę $x$ najważinejaych diwit

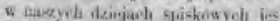

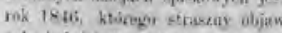

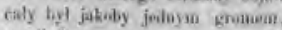

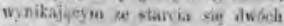
utujonych potes.

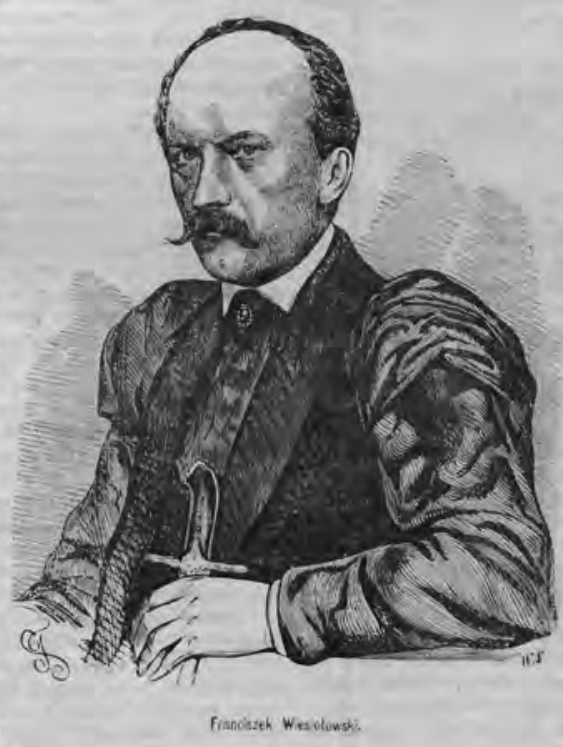

Bryy tu ietotnia dwa posegi,

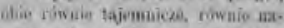

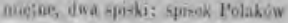

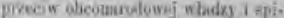

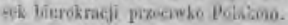

Dowe to wiallie patigi by

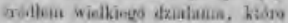

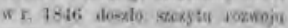

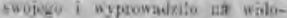

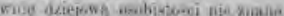

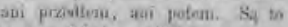

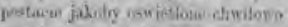

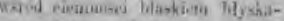

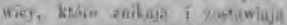

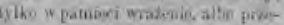

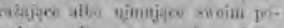

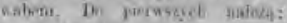

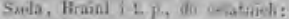
W strongki Teotil. Dave howebi Eawari. WiefieIn $n=k$ Fragedteok it at

Wiesiolowakiego wyainal nok

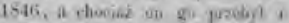

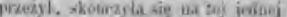

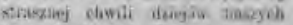

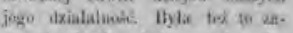
prowity clivila, ketra mogla oxloniokowi wyskuseye za caly fyont.

Sie wismy kago do reopliwyeh policxye: ay tynt 60 - xyi-

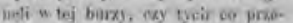
kyweny if vporkać ste musieli opos prosidadowan reglowyeh $x$ potwary i suiewagy whaspeh twecele zombios.

$$
21025 / 32
$$


na temat wyprawy lisiogórskiej, a także poprzedzających ją wydarzeń. Interesujący wydaje się fakt, że choć Wiesiołowski był aktywny w kręgach powstańczych, spotykając się z wpływowymi postaciami w kraju, to jednak nie doczekał się tak bogatych opracowań, jak chociażby inni spiskowcy - Edward Dembowski czy Jan Tyssowski, którym poświęcono liczne dzieła bądź artykuły. Tak naprawdę jedyną stricte poświęconą Wiesiołowskiemu pracą jest rozdział pt. Ostatni dziedzic Wojsławia w dziele Mariana Tyrowicza ${ }^{13}$. Pomimo braku obszernej literatury na temat jego osoby warto odnotować, że właśnie najbardziej znane dzieło szlachcica z Wojsławia, czyli Pamiętnik z r. 1845-1846, okazało się podstawową lekturą dla Stefana Żeromskiego przy powstawaniu dramatu pt. Turoń ${ }^{14}$, którego akcja toczy się w okresie rabacji galicyjskiej ${ }^{15}$. Choć Wiesiołowskiego można uznać za osobę nieco zapomnianą, to na podstawie jego prac i relacji ${ }^{16}$ można stwierdzić, że on sam oraz jego decyzje miały istotny wpływ na przebieg wydarzeń w omawianym czasie. Czy rzeczywiście był tak ważną postacią podczas przygotowań do powstania? Dlaczego ruch zbrojny w tym czasie nie mógł się udać? Jakie błędy zostały popełnione przez przywódców powstania? Czy można było ich uniknąć? Dokonując wnikliwej analizy Pamiętnika z r. 1845-1846 autorstwa Wiesiołowskiego, można przeprowadzić szczegółową analizę opisanych przez szlachcica wydarzeń poprzedzających nieudaną próbę wystąpienia przeciw zaborcy, próbując jednocześnie poznać i zrozumieć schemat myślowy jednego z głównych inicjatorów ruchu niepodległościowego.

W przeciwieństwie do Poznańskiego Galicja na początku 1846 r. zaczęła stopniowo przygotowywać się do rozpoczęcia powstania. O ile do końca stycznia wyglądało na to, że żadne zagrożenie ze strony władz austriackich nie grozi tutaj powstańcom, o tyle na początku lutego ten stan nagle zaczął się zmieniać. Już trzeciego dnia tegoż miesiąca starosta tarnowski Joseph Breinl otrzymał donos o gromadzeniu broni dla powstańców z polecenia mandatariusza Karola

13 Por. M. Tyrowicz, Wizerunki sprzed stulecia, Kraków 1968.

14 K. Poklewska, op. cit., s. 94.

15 Jedną z głównych i zarazem jedyną historyczną postacią dramatu był Jakub Szela. Akcja tego utworu rozgrywa się w nocy z 18 na 19 lutego 1846 r., czyli dokładnie w tym samym czasie co wyprawa lisiogórska. W pewnym momencie utworu następuje również nawiązanie do tych wydarzeń, których jednym z bohaterów jest Wiesiołowski. Pojawia się wzmianka o ujęciu powstańców przez chłopów i przetransportowaniu ich przez wojsko do Tarnowa. To tylko utwierdza w przekonaniu, że Żeromski korzystał z dzieła Wiesiołowskiego, podpierając się nim jako wiarygodną relacją historyczną.

16 Zob. F. Wiesiołow ski, Pamiętnik z r. 1845-46, Lwów 1868; i d e m, Ustęp z moich wspomnień, Jasło 1861; i d e m, Skarb ukryty, „Dziennik Literacki” 1844, 10, s. 308-320; i d e m, Szkice z podróży pomiędzy Jarostawiem a Lwowem w roku 1865, „Gazeta Narodowa” 8 (1866), s. 1-2; i d e m, Wegry. Ustęp $z$ moich wspomnień, „Dziennik Literacki” 7 (1861), s. 49-50; id e m, Węgry. Ustęp $z$ moich wspomnień, „Dziennik Literacki” 8 (1861), s. 58-59. 
Semetkowskiego w miasteczku Ryglice. Do aresztowań doszło tydzień później, a poza mandatariuszem schwytano również trzech mieszczan. Wówczas do dowódcy szwadronu szwoleżerów w Ryglicach zgłosił się dobrowolnie jego wachmistrz - Czech Anton Kopecký. Poinformował, że przekupiony przez Semetkowskiego został wciągnięty do akcji spiskowej, i przekazał wszelkie znane mu informacje, wspominając również, że głową spisku w Tarnowie jest Wiesiołowski. Od tamtego momentu widoczna jest zmiana w postępowaniu Breinla, który gorliwie śledził działania spiskowe. Niedawny zwolennik aresztowań informował oficjalnie, że takowe nie zdadzą się na nic i mogą jedynie rozdrażnić spiskowców ${ }^{17}$.

Fala aresztowań nie ograniczyła się jedynie do Ryglic. Po 10 lutego dyrektor policji lwowskiej Leopold Sacher-Masoch uwięził we Lwowie wielu studentów, rzemieślników i wojskowych, co dało sumę kilkudziesięciu osób i przyniosło zamierzony skutek - zahamowało akcję spiskową w tym rejonie. Jednocześnie miejscowe władze zwróciły się z prośbą do Breinla o aresztowanie Wiesiołowskiego ${ }^{18}$. Największy cios powstanie otrzymało jednak 12 lutego w Wielkopolsce. Wtedy ok. godziny 10 rano w Świniarach został zatrzymany jego niedoszły wódz Ludwik Mierosławski, co pociągnęło za sobą kolejne aresztowania. Dwa dni później do więzienia wtrącono najaktywniejszych i najbardziej wpływowych członków konspiracji: Karola Libelta, Aleksandra Guttrego, Seweryna Elżanowskiego i 20 innych spiskowców, co spowodowało zdezorganizowanie spisku w Poznańskiem ${ }^{19}$.

Informacje o aresztowaniach w Wielkopolsce nie dotarły do spiskowców w Galicji, którzy w nocy z 12 na 13 lutego spotkali się w Hoszanach u Henryka Janki²0. Na tym zjeździe zjawili się obok Wiesiołowskiego dwaj do niedawna równie czołowi, lecz od pewnego momentu zmarginalizowani przez niego działacze Dembowski i Teofil Wiśniowski - obaj działający wówczas na terenach jej wschodniej części. Ten pierwszy przekonywał swoich rozmówców, że pomimo licznych aresztowań nie warto zaniechać w tym momencie planów powstańczych. Ustalono, że Wiesiołowski uda się do Tarnowskiego, a dwaj pozostali zajmą się dowodzeniem w okolicach Lwowa. Oznaczało to sprzeciwienie się krakowskim ustaleniom ze stycznia, kiedy to powstańczemu wielkorządcy Galicji nakazano, by wraz z Wiśniowskim oczekiwał chwili wybuchu powstania w Jordanowie (obwód sądecki),

17 S. Kieniewicz, op. cit., s. 127-128.

18 M. Żychowski, op. cit., s. 169.

19 B. Limanowski, Ostatnie lata dziejów powszechnych: od 1846 r. do dni dzisiejszych, Lwów 1881, s. $152-153$.

20 Henryk Janko (1807-1887) - działacz społeczny i polityk, uczestnik powstania listopadowego i styczniowego. Zaangażowany w działalność konspiracyjną, goszczący w swoim dworze w Hoszanach wielu spiskowców. 
gdzie miał proklamować się galicyjski rząd narodowy ${ }^{21}$. Tymczasem zaskakująca okazała się postawa Breinla względem dziedzica Wojsławia. Co prawda 11 lutego zwrócił się do gubernium z prośbą o pozwolenie na jego aresztowanie, ale pismo to rozminęło się z rozkazem arcyksięcia Ferdynanda d'Este z dnia wcześniejszego, by uwięził go nawet w przypadku braku dowodów. Starosta tarnowski ponowił zapytanie 13 lutego, jakby celowo odwlekając ostateczne uwięzienie głównodowodzącego powstania. Otrzymując dwa dni później bezwarunkowy rozkaz aresztowania Franciszka i jego młodszego brata Michała Wiesiołowskiego, zmuszony, zgodził się, wysyłając jednak sprzyjających Polakom urzędników, którzy nie zastawszy braci $\mathrm{w}$ Wojsławiu, powrócili do miasta ${ }^{22}$. Jak podano w Pamiętniku Wiesiołowskiego, ten przyjechał właśnie 15 lutego na noc do domu, wróciwszy z Rzeszowszczyzny. Możliwe, że faktycznie rozminął się z urzędnikami, lecz niewykluczone, że Breinlowi zależało pozostawić dziedzica Wojsławia na wolności. Sugerując się późniejszymi wydarzeniami, tarnowski starosta mógł nosić się z zamiarem obserwowania jego czynów, aby podczas próby wzniecenia ruchu zbrojnego spacyfikować F. Wiesiołowskiego wraz z innymi spiskowcami z pomocą podżeganych przeciw szlachcie chłopów.

W odniesieniu do sposobu przeprowadzenia powstania istniały dwa nurty. Jeden, którego zwolennikiem był F. Wiesiołowski, przewidywał zaangażowanie jedynie pojedynczych ochotników, a nie całych mas chłopskich. Siła miała zostać oparta na szlachcie, oficjalistach prywatnych, służących dworskich czy mieszczanach. Dopiero po rozbrojeniu władzy planowano zapowiedzieć swobody na rzecz włościan, po czym mieli oni dołączyć do rebeliantów. Jak sam zwolennik tego planu podkreślał, obawiano się nie agresji, lecz obojętności chłopów, co - jak się potem okazało - było bardzo mylnym założeniem. Druga koncepcja, za którą opowiadał się chociażby M. Wiesiołowski, zakładała zwołanie całych gromad chłopskich, ogłoszenie przyznania im swobód i pociągnięcie za sobą w celu pomocy w obaleniu władzy, co również z uwagi na postępującą propagandę rządu nie przyniosłoby skutku.

Dnia 16 lutego F. Wiesiołowski miał za zadanie zebrać ostateczne raporty, aby z gotowymi materiałami stanąć dzień później w Tarnowie, gdzie pod pretekstem balu fantowego miały odbyć się ostateczne narady. Tego samego dnia wieczorem został poinformowany o decyzji o przyspieszeniu wybuchu powstania na 18 lutego, co - jak sam twierdził - było efektem wzmożonych aresztowań. Po usłyszeniu tej informacji postanowił jeszcze nocą udać się do Tarnowa. Rankiem po dotarciu

${ }_{21}$ S. Nicieja, M. Patelski, Rok 1846 we Lwowie. Stracenie Kapuścińskiego i Wiśniowskiego i ich kult we Lwowie, [w:] Rok 1846 w Galicji..., s. 83-84.

22 S. Kieniewicz, op. cit., s. 128-129. 
do miasta spotkał się z Ksawerym Barzyńskim, który potwierdził zmianę terminu wybuchu powstania wyznaczoną przez Leona Czechowskiego, dowódcę obszaru wojskowego Tarnowa. Poinformował jednocześnie wielkorządcę Galicji o konieczności opuszczenia miasta wobec nakazu aresztowania go wydanego przez władze austriackie. Dziedzic Wojsławia, stosując się do wskazówek, postanowił udać się do Gumnisk - podtarnowskiej rezydencji księcia Władysława Sanguszki - okrężną drogą ${ }^{23}$. Jak się jednak w istocie okazuje, aresztowanie F. Wiesiołowskiego nie musiało być takie oczywiste. Gdy ten zjawił się w biały dzień w mieście, nie stanowiło to tajemnicy, bowiem nie był on już wtedy osobą anonimową. Breinl, zamiast dopilnować dokonania aresztowania, kazał wystosować na piśmie jeszcze jeden rozkaz pojmania. Wręczył go nadkomisarzowi Brezaniemu, który jako zwolennik Polaków wcale nie kwapił się do jego wykonania. W ten sposób po raz kolejny szlachcic uniknął niemal nieuchronnego więzienia, zbiegając, poinformowany na czas, na miejsce spotkania z Czechowskim. W gruncie rzeczy wydaje się, że działania te mogły być zaplanowane przez zawsze niechętnego szlachcie Breinla. Sam doskonale znał antagonizmy dzielące chłopów i dziedziców i postanowił to łatwo wykorzystać. Najpierw obiecywał włościanom nagrody za śledzenie i chwytanie spiskowców, by zaszczepić w nich nieufność względem powstańców. Prawdopodobnie przed 10 lutego zaczął już jawnie zachęcać ich do samodzielnego wystąpienia przeciw szlachcie, co tłumaczy wstrzymanie aresztowań w końcowej fazie przygotowań zrywu niepodległościowego w Galicji. Te działania skutkowały wspomnianą przez Wiesiołowskiego w Pamiętniku tzw. drugą paniką chłopską, przypominającą pierwszą taką panikę z Wielkanocy roku ubiegłego ${ }^{24}$. Jak opowiada: „chłopi poczęli czynić zeznania, w kilku miejscach zaczęli oni już stawiać warty po drogach i napastować przejeżdżających; widzieliśmy wtedy, iż się na coś złego zanosi” ${ }^{25}$. Wielkorządca Galicji zdawał sobie sprawę, że konspiracja zaszła tak daleko, że niemożliwe i nierozsądne byłoby rezygnować z powstania pomimo tych niepokojących okoliczności. Dokładnie o tych samych blokadach, lecz w nieco innym regionie i późniejszym czasie wspomina w swym dzienniku młoda szlachcianka Marianna Pikuzińska, która 20 lutego wracała z Krakowa w Bocheńskie do swojego dworu w Dołędze, zdając w ten sposób relację z ostatnich wydarzeń przed nadchodzącą rabacją galicyjską ${ }^{26}$.

Kolejnym miejscem docelowym F. Wiesiołowskiego po zbiegnięciu z Tarnowa był dworek Sanguszki w Gumniskach. Przeciwny zrywowi niepodległościowemu

23 F. Wiesiołowski, Pamiętnik..., s. 89-91.

24 S. Kieniewicz, op. cit., s. 129, 132-33.

25 F. Wiesiołowski, Pamiętnik..., s. 86.

26 M. Pikuzińska, Dziennik Marianny Pikuzińskiej, [w:] Rabacja na Powiślu..., s. 31. 
arystokrata, przeczuwając, że powstanie może narazić go na wybuch ze strony chłopów, przekazał władzom austriackim swoją wiedzę na temat postępujących przygotowań. Następnie wyjechał do Paryża, nie chcąc uczestniczyć w nadchodzących wypadkach ${ }^{27}$. Nie stanowił odosobnionego przypadku, gdyż podobnych jak on - obawiających się wojny ludowej (jak chociażby Wincenty Pol) - było więcej, co z pewnością jeszcze bardziej uniemożliwiło porwanie za sobą mas chłopskich $^{28}$. Na dziedzica Wojsławia czekał już Czechowski, a w spotkaniu uczestniczyli ponadto Barzyński i Józef Machowicz. Główny punkt spotkania stanowiła debata na temat przyspieszenia terminu powstania (na noc 18/19 lutego). Decyzję tę podjął samodzielnie Czechowski, a F. Wiesiołowski stanął przed wyborem, czy zmienić termin na poprzedni (noc 21/22 lutego) - ryzykując rozbiciem kilku oddziałów, które nie zostaną już o tym na czas poinformowane - czy zgodzić się z zarządzeniem Czechowskiego. Ostatecznie, pozostając bez instrukcji od władzy krakowskiej, bojąc się pokrzyżowania planów i w obliczu aresztowań we Lwowie i Poznaniu, o których już doszły informacje do Galicji, zdecydował się przystać na nowy termin. Wielkorządca Galicji obawiał się także posądzenia o tchórzostwo czy zdradę, co znacząco osłabiłoby jego pozycję ${ }^{29}$. Przyspieszenie terminu nie oznaczało tego w istocie dla całej Galicji. W pozostałych obwodach pozostawała stara data 21/22 lutego, toteż gdy tarnowscy spiskowcy zostali rozbici, na innych terenach dopiero rozpoczynały się działania. Skuteczne manewry komplikowała natomiast masa chłopska, która pod wpływem wydarzeń w Tarnowskim działała coraz szerszą falą ${ }^{30}$. Pomimo ciężkiej sytuacji, w jakiej znalazło się mające nadejść powstanie w Tarnowie, F. Wiesiołowski wielką nadzieję upatrywał w liczbie atakujących, która go satysfakcjonowała. Co więcej, sam Sacher-Masoch uważał, że miastu groziło wielkie niebezpieczeństwo, a liczba 700 żołnierzy - w tym głównie Polaków - nie dawała poczucia spokoju. Szef policji lwowskiej twierdził, że komendant tarnowski baron Czolitch uważał wręcz sprawę za straconą, lecz na jego szczęście skuteczna okazała się propaganda wśród chłopstwa ${ }^{31}$. Plan militarny Czechowicza przewidywał dwa punkty zborne - Klikową ( $3 \mathrm{~km}$ na północny zachód od Tarnowa) i Tarnowiec ( $2 \mathrm{~km}$ na południe od miasta). Miały one stanowić punkt zbiórki w nocy z 18 na 19 lutego, a za sygnał do ataku uznano podpalenie karczmy na Górze św. Marcina niedaleko Tarnowca ${ }^{32}$.

27 S. Kieniewicz, Sanguszko Władysław Hieronim, [w:] „Polski Słownik Biograficzny T. XXXIV” red. Marki ewicz H., Wrocław-Kraków-Warszawa 1992-1993, s. 514-517.

28 J. Rosnowska, Dzieje poety: opowieść o Wincentym Polu, Warszawa 1973, s. 208-209.

29 M. Tyrowicz, op. cit., s. 172-173.

30 M. Żychowski, op. cit., s. 175.

31 B. Lim a nowski, Historia ruchu rewolucyjnego w Polsce w 1846 r., Kraków 1913, s. 163.

32 M. Żychowski, op. cit., s. 175-176. 
Wieczorem po naradach F. Wiesiołowski udał się drogą przez Przecław do Kiełkowa, gdzie mieszkał Jan Gumiński. Zajechawszy na godzinę 8 rano, dowiedział się, że jego brat Michał poinformował gospodarza o wcześniejszym terminie wybuchu powstania, o którym dowiedział się w Tarnowie, i zdążył już wrócić do Wojsławia. Tam, w czasie pobytu Franciszka w Tarnowie, z wizytą we dworze po wielkorządcę Galicji stawił się komisarz Bartmański z żołnierzami. To sprawiło, że M. Wiesiołowski i Gumiński, przekonani o uwięzieniu dziedzica Wojsławia, postanowili działać sami. Posłali swoich ludzi do dworu F. Wiesiołowskiego po strzelby. Ci wobec ciężkich warunków pogodowych powrócili dopiero po przyjeździe F. Wiesiołowskiego, który jednocześnie wyprawił zaufanego furmana, by zebrał z okolicy ochotników do udziału w powstaniu i stawił się z nimi przy włościach M. Wiesiołowskiego w Goleszowie. Młodszy z braci o przyspieszeniu terminu wybuchu walk miał się dowiedzieć 17 lutego w Tarnowie, dokąd przyjechał, powracając z Sanockiego ${ }^{33}$. Była to prawdopodobnie jedna z dwóch wizyt Michała $\mathrm{w}$ tamtym regionie, o których wspomina Kieniewicz (pierwsza w grudniu 1845 r.). Ich cel stanowiła praca nad zjednaniem majętniejszej szlachty ${ }^{34}$. Dowiedziawszy się o szykowanym aresztowaniu siebie i brata, Michał zbiegł z miasta, zatrzymując się jeszcze w Kiełkowie u Gumińskiego.

Od momentu, kiedy zaczął zbierać chłopstwo i dołączył do niego brat, ta ich wspólna ekspedycja w kierunku Lisiej Góry stanowi centralny i kulminacyjny punkt Pamiętnika Wiesiołowskiego. Opis wyprawy autorstwa dziedzica z Wojsławia odtwarzający nieudaną próbę dostania się do Tarnowa jest najbardziej szczegółowym spośród wszystkich źródeł relacjonujących to wydarzenie. O ile F. Wiesiołowski zajmował się koordynacją całego ruchu i skupiał wokół siebie szlachtę, o tyle jego brat Michał w decydującym momencie powstania postanowił pociągnąć za sobą masy chłopskie. Dokładny opis tej mobilizacji przez dziedzica Goleszowa przedstawia duchowny Wojciech Michna ${ }^{35}$. M. Wiesiołowski zwołał do siebie wójta Walentego Kwaśniewskiego, kmieci Jakuba Cieślę, Kisiela, Marka Mazura i innych, których informował jeszcze na początku lutego o zbliżającej się akcji. Efektem tego miało być zakupienie na targu przez kowala Stanisława Brockiego i innych mieszkańców Radomyśla Wielkiego wszystkich dostępnych kos. W decydujący dzień Michał spotkał się z Kwaśniewskim i Kisielem w niedalekim leśnictwie, gdzie nakazał im zebranie powstańców i zameldowanie się w jego dworze, dokąd sam udał się na wozie wyładowanym bronią. Po przyjeździe na swoje włości nie zastał nikogo z dworzan, bowiem ci zajmowali się w dalszym

33 F. Wiesiołowski, op. cit., s. 93-94.

34 S. Kieniewicz, op. cit., s. 165.

35 W. Michna, op. cit. 
ciągu werbowaniem ochotników. Najaktywniejszy w terenie miał być parobek dworski Tomasz Szarek, który zebrał 30 ochotników, a każdy z nich miał otrzymać nowe buty, sukmanę, czapkę i 3 cwancygiery na zakup strzelby lub kosy. W oczekiwaniu na długo niezjawiający się oddział M. Wiesiołowski postanowił udać się po niego osobiście, a w drodze natknął się na kilkunastu idących w stronę dworu chłopów, których udało mu się zwerbować. Wszyscy zaczęli kierować się do folwarku dzierżawcy Stanisława Kłobukowskiego, który dołączył wraz z nowo dochodzącymi ochotnikami do spiskowców. Na miejscu M. Wiesiołowski odczytał akt pisemny, w którym zrzekał się pańszczyzny, danin i innych powinności, podpisany przez siebie, żonę i świadków, uroczystą przysięgą na krucyfiks i zaprzysiężeniem. Podczas tych wydarzeń wielu chłopów znajdowało się na jarmarku w niedalekim Przecławiu, dokąd według informacji mieli wkrótce przybyć austriaccy szwoleżerowie. Zdecydowano tam oddelegować wartę złożoną z urlopników, a wraz z M. Wiesiołowskim w kierunku Kiełkowa udali się synowie i parobkowie gospodarzy wiejskich. Przed wyruszeniem dokonało się jeszcze uroczyste postawienie poświęconej chorągwi z Opatrznością Boską i białym orłem, z którą ruszono dalej w drogę.

W Kiełkowie dołączyli Gumiński z F. Wiesiołowskim i wszyscy udali się ponownie do włości M. Wiesiołowskiego w Goleszowie, gdzie oczekiwano na posiłki z Wojsławia. Sytuacji nie ułatwiała pogoda - burza śnieżna paraliżowała szybką komunikację $e^{36}$. Wynikiem tego posiłki z posiadłości F. Wiesiołowskiego przybyły dopiero wieczorem, a byli wśród nich m.in. miejscowy wójt Tomasz Sarana, który osobiście przyprowadził swojego zięcia Marka Mazura. Równocześnie podziękował za zniesienie pańszczyzny ${ }^{37}$. Niewiele później ten sam wójt, gdy tylko dowiedział się o niepowodzeniu powstańców, miał namawiać do napaści na włości wielkorządcy Galicji w Wojsławiu, w wyniku czego żona, matka i dzieci F. Wiesiołowskiego zmuszone były schronić się w odległej o ok. 30 km Kolbuszowej. Jak potwierdza Kieniewicz, chłopi nie okazali się tu jednak tak brutalni jak na wielu innych terenach. Ograniczyli się do rabowania spiżarni i garderoby, nie niszcząc mebli, zostawiając spichlerz i obory, nie czyniąc również nikomu $\mathrm{krzywdy}^{38}$. Organizatorem tego ataku była najprawdopodobniej grupa niejakiego chłopa Twaroga, pochodzącego z Zabrnia odległego o $30 \mathrm{~km}$ na zachód od Mielca, najaktywniejsza na tych terenach ${ }^{39}$. $\mathrm{Z}$ kolei zięć wójta, który miał pomóc

\footnotetext{
36 W. Michna, op. cit., s. 68-69; F. Wiesiołowski, op. cit., s. 95-98.

37 K. Ostaszewski-Barański, op. cit., s. 89.

38 S. Kieniewicz,op. cit., s. 206.

39 K. Groniowski, Uwłaszczenie chłopów w Polsce. Geneza, realizacja, skutki, Warszawa 1976, s. 90 -91 .
} 
powstańcom, osobiście w stroju chłopa zbiegł pod Lisią Górę i walczył przeciwko nim. Nie stanowiło to odstępstwa od reguły, gdyż wielu innych włościan postąpiło podobnie, co stanowiło tylko dowód braku świadomości narodowej tej grupy społeczeństwa.

Zebrawszy się pomiędzy godziną 17 a 18, po zachodzie słońca, wyruszono kilkoma saniami i wozami. W Pamiętniku Wiesiołowski wspomina o grupie czterdziestokilkuosobowej ${ }^{40}$, podczas gdy w swych zeznaniach śledczych (z uwagi na bliższe wspomnieniu prawdopodobniejsze) wylicza wszystkich na 30 ludzi, na czele których znajdowali się bracia Wiesiołowscy, Gumiński i Kłobukowski ${ }^{41}$. Zważając jednak, że wielu uczestników wyprawy nie dotarło pod Lisią Górę, niewykluczone, iż F. Wiesiołowski podawał w zeznaniach liczbę jedynie panów, pomijając chłopów ${ }^{42}$. W Rudzie pod Radomyślem zorganizowano pierwszy postój, bowiem Kłobukowski postanowił wstąpić do pobliskiego dworu, by zabrać stamtąd dzierżawcę, żądając równocześnie kolejnego konia do zaprzęgu, gdyż zaprzęg ze względu na wielki śnieg poruszał się z trudem. Reszta uczestników wyprawy w tym czasie ogrzewała się w pobliskich chatach i niewykluczone, że już wtedy możliwe były pierwsze odłączenia się chłopów. O godzinie 21 udało się dotrzeć do Radomyśla i dalej przez Żarówkę przemieszczano się pustymi drogami, na których panowały spokój i cisza. Nim dojechano do odległej o $20 \mathrm{~km}$ od Tarnowa Jastrząbki, wiadomym się stało, że pojawienie się w wyznaczonym punkcie o godzinie $2 \mathrm{w}$ nocy jest niemożliwe ze względu na fatalne warunki atmosferyczne. Tam w karczmie Wesoła powzięto istotną decyzję. W związku z dołączeniem do załogi byłego oficera gwardii grenadierów Gromczewskiego ${ }^{43}$ i młodego Wilhelma Romera postanowiono, że tej dwójce zostanie powierzone dowództwo nad zebranym oddziałem, podczas gdy bracia Wiesiołowscy, Gumiński i Kłobukowski sami udadzą się do wyznaczonego punktu, by zdążyć na czas i dołączyć do pozostałych oddziałów $w^{44}$. Dodatkowo miało miejsce spotkanie z tamtejszym dziedzicem Brodzkim. Ten odmówił przyłączenia się do powstańców, wspominając o nich wręcz z ironią.

Czwórka powstańców kierowała się teraz samotnie w stronę Lisiej Góry. Wieś odległa o $8 \mathrm{~km}$ na północ od Tarnowa znajdowała się w „państwie tarnowskim” Sanguszków otaczającym miasto od północny i wschodu. Choć dawniej

\footnotetext{
F. Wiesiołowski, op. cit., s. 100.

S. Kieniewicz, op. cit., s. 151.

W. Michna podaje, że grupa przed wyruszeniem liczyła 40 panów i 30 włościan.

Dziedzic Wojsławia wspomina o nałogach byłego oficera, który nie nadawał się na dowódcę oddziału, a którym z konieczności go mianowano.

${ }_{44}$ F. Wiesiołowski, op. cit., s. 101-102.
} 
w dzierżawie, to od czterech lat urzędował w niej rządca, na którego skarżyli się miejscowi chłopi z powodu wysyłania ich do pracy w odległych folwarkach. Administracja dodatkowo uciskała włościan, a wójtowie ślepo słuchali cyrkułu. Ówczesny rządca Józef Stelmach jeszcze dzień przed krwawymi wydarzeniami miał stawić się osobiście u Breinla, by potem dać sygnał do łapania i mordowania powstańców, w związku z czym, jako jeden z nielicznych przywódców chłopskich, po wydarzeniach lutowych pozostawał $\mathrm{w}$ przyjaznych stosunkach $\mathrm{z}$ władzą ${ }^{45}$. Michna rozróżnia „piekielną trójkę zbójecką z rabacji”, w skład której wchodzić miały Ciężkowice (Koryga), Pilzno (Szela) i właśnie Lisia Góra. Nie wspomina nic o przywódcy tej grupy, lecz nie zmienia to faktu, że Stelmach odegrał istotną rolę w zmobilizowaniu włościaństwa do ataków, które obejmowały tereny pomiędzy Bochnią, Dąbrową Tarnowską i Tarnowem ${ }^{46}$. Nim czwórka powstańców dotarła na miejsce, przybył tam niewielki oddział innych powstańców z Józefem Kapuścińskim, który wraz z kilkunastoma innymi powstańcami uprzednio wtargnęli do Pilzna i zamordowali tamtejszego burmistrza Kaspra Markla. Ich podboje zakończyły się w Lisiej Górze, gdzie śmierć poniósł jeden ze spiskowców, resztę odstawiono do Tarnowa ${ }^{47}$. Ofiarą napaści został również tamtejszy proboszcz ks. Stanisław Morgenstern, który zasłużył się wcześniej doprowadzeniem do 4700 ślubów wstrzemięźliwości w liczącej 8 tys. wiernych parafii. Zaprowadzona na szerszą skalę akcja wstrzemięźliwości przynosiła bardzo owocne skutki, lecz propaganda rządu i namawianie „do kieliszka” spowodowały wzmożoną agresję chłopów, którzy zaczęli zwracać się także przeciwko miejscowym księżom ${ }^{48}$. Ksiądz Morgenstern miał tuż przed samym przyjazdem grupy Wiesiołowskich wygłosić patriotyczną przemowę do zebranej tam bandy chłopskiej, lecz nie napotkawszy oddźwięku, został przez nią pochwycony, a następnie odstawiony do Tarnowa ${ }^{49}$.

Wracając do F. Wiesiołowskiego, ten wraz z trójką towarzyszy ok. godziny 5 nad ranem dotarł do Lisiej Góry. Przejeżdżając przez wieś, pomimo świateł w oknach, nie napotkali oni nikogo, lecz zaraz po jej minięciu dotarli do rozwidlenia, gdzie łączą się drogi na Tarnów, Pilzno i Dąbrowę Tarnowską. Zaraz przy nim znajdowała się karczma, przy której koczowali już chłopi ${ }^{50}$. Co do

\footnotetext{
45 S. Kieniewicz, op. cit., s. 151, 157.

46 W. Michna, op. cit., s. 66.

47 J. B e d n arek, Spory wokół wydarzeń krajowych 1846 roku na łamach prasy Wielkiej Emigracji w latach 1846-1848, Toruń 2003, s. 195; S. D e mbińs ki, op. cit., s. 208.

48 J. Kracik, W Galicji trzeźwiejącej, krwawej, pobożnej, Kraków 2007, s. 31-32.

49 M. Żychowski, op. cit., s. 179.

50 W. Michno, op. cit., s. 69-70; S. De mbiński, op. cit., s. 209.
} 
liczby włościan - w zeznaniach śledczych dziedzic Wojsławia oszacował ją na 80-100 osób ${ }^{51}$. Wówczas próbował przemówić do chłopów, co nie przyniosło skutku, więc zagłuszeni powstańcy postanowili oddać się w ich ręce. Co prawda nim to zrobili, F. Wiesiołowski był gotowy strzelać w tłum, lecz odwiódł go od tego brat Michał, nie chcąc rozpoczynać powstania od zabijania ludu. W efekcie po wyjściu z bryczki ${ }^{52}$ wszyscy przybyli zostali związani. Wówczas mocno ranił się Kłobukowski, którego obrażenia okazały się na tyle poważne, że niebawem zmarł. Zarówno w Pamiętniku, jak i w większości opracowań podano, że chcąc się bronić przed skrępowaniem, wyciągnął nóż. Ten wypadł mu z ręki ostrzem do góry, a szlachcic w niefortunny sposób przewrócił się na niego ${ }^{53}$. Inaczej tę sytuację ocenia Kieniewicz, opierając się na zeznaniach śledczych wielkorządcy Galicji, w których ten mówił o pchnięciu sztyletem jako o zamiarze samobójczym. Rannego chłopi położyli na stole w karczmie, do której zaprowadzono również powiązanych pozostałych szlachciców. Najpierw nie używano przemocy wobec powstańców, poprzestając jedynie na obelgach, wyrzucając im chęć powybijania chłopów. Prawdopodobnie brak agresji wiązał się z początkowym strachem przed rzuceniem się na bezbronnych. $Z$ tego powodu decydowali się na przekazywanie powstańców szwoleżerom, którzy po przybyciu z Tarnowa zabierali pojmanych do miasta ${ }^{54}$. W karczmie, do której zaprowadzono pojmanych, przetrzymywani już byli niektórzy członkowie grupy Kapuścińskiego. Obwiązani wysłuchiwali obelg nie tylko chłopów, ale także kobiet i dzieci, a M. Wiesiołowskiego, „mającego wygląd ponury i surowy, lżyli nawet okropnie" 55 . Szlachcice próbowali przemówić do swych włościan, co - jak podaje F. Wiesiołowski - wzbudziło nawet zainteresowanie przetrzymujących, lecz na przeszkodzie w dalszej komunikacji stanął hałas, który dochodził z zewnątrz ${ }^{56}$. Wówczas pod karczmą stanął liczący najprawdopodobniej 48 osób oddział ${ }^{57}$, który w Jastrząbce został przez Wiesiołowskich oddany w ręce Gromczewskiego i Romera. Były oficer okazał się

51 S. Kieniewicz, op. cit., s. 157. W porównaniu z informacjami w Pamiętniku zachodzi tu spora różnica, gdyż podaje w nim, że czekało na nich 200 chłopów, co wydaje się mniej prawdopodobne.

52 W niektórych opracowaniach pojawia się informacja, że powstańcy przybyli na saniach, co zważając na panujące wtedy warunki pogodowe, wydaje się jak najbardziej możliwe. Zważając jednak na fakt, że gwałtowna śnieżyca kompletnie zaskoczyła spiskowców, niewykluczone, że nie pomyślano wówczas o skorzystaniu z sań, które byłyby znacznie przydatniejsze.

53 F. Wiesiołowski, op. cit., s. 102.

54 S. Dembiński, op. cit., s. 209.

55 S. Kieniewicz, op. cit., s. 157.

56 F. Wiesiołowski, op. cit., s. 103.

57 Zakład Narodowy im. Ossolińskich we Wrocławiu, rkps 2003/I, k. 4, H. Żele ń ska, Notatki wypadków niektórych dziejących się w Galicyi od 18 lutego [1]846 roku. 
pierwszą osobą, która opuściła broń, zaś jego młodszy kompan osobiście pilnował, by nikt nie oddawał strzałów. Skończyło się tylko na dwóch, które dość skutecznie odstraszyły chłopów czekających przed karczmą i wywabiły z niej tych, którzy wówczas rozmawiali $\mathrm{z}$ uwięzionymi. Ze strachem zaczęli pertraktować z przybyłymi, prosząc o opuszczenie broni, w zamian zapewniając, że wypuszczą uwięzionych. Natychmiast po rozbrojeniu gromada rzuciła się na oddział, lecz w odróżnieniu od zatrzymanej poprzednio grupy powstańców chłopi okazali się agresywniejsi, wprowadzając ich na siłę do budynku. Wówczas zmienił się stosunek włościan do poprzednio uwięzionych, a sam F. Wiesiołowski wspomina o wściekłej chłopce, która uderzyła go pięścią w twarz, na co oddał jej kopniaka, po którym dostał kolejne razy od innych. Wszystkich wepchnięto do piwnicy, gdzie przez małe okienko oczekiwali na wojsko, które w ich mniemaniu miało uchronić powstańców od mocniejszego pobicia ${ }^{58}$.

Co stało się z innymi oddziałami mającymi wspomóc tych, którzy kierowali się przez Lisią Górę? Obok Radomyśla Wielkiego w Partyni Jan Góra z mandatariuszem Dworzańskim usiłowali zachęcić do udziału w powstaniu parobków i urlopników, co podobnie jak w innych wsiach na linii Goleszów-Radomyśl-Jodłówka nie spotkało się z odzewem. We wspomnianej Partyni, tuż przy karczmie Wytrząska, jeszcze w nocy z 18 na 19 lutego doszło do blokady chłopskiej, która skończyła się atakiem i zabiciem pięciu szlachciców - był to najprawdopodobniej pierwszy atak chłopów na powstańców. Oddziały kierujące się z innych stron na Tarnów, przeważnie ze względu na brak określonych sygnałów, bądź rozproszyły się, bądź zostały spacyfikowane podobnie jak ten w Lisiej Górze. Z kolei chłopi, którzy przyłączyli się do oddziałów jeszcze w trakcie drogi bądź w momencie napadów chłopskich, włączali się do gromad, napadając i rabując w okolicy ${ }^{59}$.

Około godziny 9 rano wraz z całym szwadronem konnicy pojawił się ppłk Ludwig, a jego oddział wyciągnął pojmanych z piwnicy i umieścił przed karczmą. Oczekując na swój los, F. Wiesiołowski rozpoznał znajomych wśród żołnierzy, z których w swych wspomnieniach z eskorty do Tarnowa pozytywnie wspominał później jedynie oficera Berlichingena i por. Bierfeldnera ${ }^{60}$. Ci, w przeciwieństwie do innych, nie zezwalali na ciosy od chłopów, które w obecności wojska otrzymał i w efekcie których zalał się krwią. Pomimo to Ludwig stanowczo zastrzegł, że w przypadku próby ucieczki któregokolwiek z pojmanych wojsko otworzy

58 F. Wiesiołowski, op. cit., s. 103-105.

59 M. Żychowski, op. cit., s. 176-177, 179-180; Relacje chłopskie o krwawych wydarzeniach 1846 r., [w:] Rabacja na Powiślu..., s. 59-60.

60 S. Dembiński, zamiast niego, wspomina oficera Birkenfelda. Najprawdopodobniej była to ta sama osoba, lecz nie wiadomo, który z autorów podaje właściwe nazwisko oraz stopień wojskowy. 
ogień $^{61}$. Poza wspomnianymi dobrodusznością wykazał się jeszcze ppłk Moltke, lecz najprawdopodobniej takie przykłady stanowiły jedynie wyjątek od reguły ${ }^{62}$. Podczas dalszej drogi do Tarnowa F. Wiesiołowski chronił się przed kolejnymi uderzeniami rozwścieczonych włościan, biegiem dotrzymując kroku koniom żołnierzy. Sytuacja zmieniła się podczas pokonywania ostatniego wzniesienia przed wjazdem do Tarnowa, kiedy to nakazano wsiąść mu na sanie szlachcica Worczyńskiego, którego zatrzymano wcześniej przypadkowo, gdy jechał do swojej kamienicy w Tarnowie. Wjeżdżając do miasta, złapani powstańcy spotykali na ulicach tłumy rozwścieczonych ludzi, którzy wyzywali ich od rabusiów i złodziei. Tuż przed rynkiem, na ul. Brama Pilzneńska - jak relacjonuje F. Wiesiołowski zrobił się szmer, gdyż chłopi po pościgu dorwali kolejną przypadkową ofiarę. To dowodzi apolityczności ruchu chłopskiego, który raczej wynikał z podsycania go i ciężkiej sytuacji życiowej tego stanu. Pechowcem okazał się pomocnik adwokata Hieronim Kunaszewski, który - podobnie jak Worczyński- bez winy i z przypadku musiał spędzić w areszcie kilka miesięcy ${ }^{63}$.

Podczas opisywanych wydarzeń na rynku tarnowskim, „[p]rzed gmachem starostwa, naprzeciw hotelu krakowskiego, całe kałuże krwi czerwieniły się na śniegu" ${ }^{4}$. Miasto przedstawiało się w sposób przerażający: co chwila przywożono rannych i nieżywych szlachciców, których składano przed cyrkułem. Ulicami włóczyli się chłopi i urlopnicy, grożąc inteligencji schowanej we własnych mieszkaniach ${ }^{65}$. Wokół zwożonych kręcili się Żydzi, wśród których prym miał wieść Izaak Luxenberg - widziany z okna przy ul. Brama Pilzneńska - triumfalnie spoglądający na zwożonych szlachciców. Żydzi ci mieli prowadzić handel złupionymi rzeczami i wyłudzać pieniądze od plądrujących dwory. Należy też jednak pamiętać, że wielu starało się również ratować szlachciców przed nieuchronną zagładą $\mathrm{z}$ rąk rozjuszonych chłopów ${ }^{66}$.

Po pewnym czasie przyszedł rozkaz, aby pojmani zostali odstawieni przez wojsko do celi. F. Wiesiołowski zaprowadzony na piętro w sztokhauzie oczekiwał na korytarzu, aż wreszcie cały zakrwawiony (wraz z Worczyńskim) został zamknięty w celi. W ten sposób zakończył się epizod w Lisiej Górze, który „nim dobrze się zaczął, już dobiegł końca" ${ }^{\prime \prime}$. Był on tym samym epilogiem zdławionego w zarodku powstania tarnowskiego, dając początek krwawej rabacji galicyjskiej,

\footnotetext{
${ }^{61}$ F. Wiesiołowski, op. cit., s. 105-106.

62 K. Ostaszewski-Barański, op. cit., s. 93; S. Dembiński, op. cit., s. 211.

63 F. Wiesiołowski, op. cit., s. 106-108.

64 L. Dębicki, Z dawnych wspomnień 1846-1848, Kraków 1903, s. 52.

65 K. Ostaszewski-Barański, op. cit., s. 98.

${ }^{66}$ L. Dębicki, op. cit., s. 52.

67 F. Wiesiołowski, op. cit., s. 108-109.
} 
którą dziedzic Wojsławia spędził już za kratami więzienia. Początkowo były to ponad dwa miesiące $\mathrm{w}$ Tarnowie, a następnie został przetransportowany do Lwowa, gdzie wyszedł na wolność w marcu 1848 r. na mocy amnestii ogłoszonej w związku z wydarzeniami Wiosny Ludów. W żadnym innym momencie swojego życia politycznego nie miał już tak ważnego udziału, usuwając się na bok i skupiając na twórczości literackiej. Tymczasem Galicja pogrążyła się na pewien czas w chaosie, stając się miejscem napadów i plądrowania dworów szlacheckich przez rozjuszonych chłopów. Między innymi doświadczenia tamtych wydarzeń zaowocowały później innym podejściem do sprawy włościan przy kolejnych próbach podejmowania walk o niepodległość.

Choć zaprezentowany powyżej wątek to jedynie opis wydarzeń trwających kilka dni, to przedstawia pewien zarys problemu. Szansa na powodzenie planów spiskowców tak naprawdę już w przededniu zrywu była niewielka. Aresztowanie niedoszłych powstańców z Wielkopolski, brak możliwości sprawnej komunikacji pomiędzy środowiskami spiskowymi obu części Galicji czy wreszcie nagłe aresztowania $\mathrm{w}$ tym regionie rozpoczęte przez władze austriackie w przededniu planowanego ataku okazały się problemami nie do przeskoczenia. Plan obalenia władz, niepozbawiony niedociągnięć, sam w sobie powodował trudności. W obliczu dodatkowych niekorzystnych zdarzeń doprowadził do chaotycznej decyzji o przyspieszeniu ataku, lecz jedynie w okolicach Tarnowa. Być może sam atak miałby jakąkolwiek szansę powodzenia - przynamniej czasowo - jak miało to miejsce w Krakowie ${ }^{68}$. Możliwość przeprowadzenia ataku została jednak zaprzepaszczona przez postawę chłopów. Zdaje się, że właśnie ten fakt najbardziej zaskoczył szlachtę. Powodów negatywnego podejścia chłopów można szukać na wielu płaszczyznach. Głównym okazały się relacje pomiędzy szlachtą a włościanami. Jak zostało przedstawione powyżej, jednym z głównych celów spiskowców było zniesienie pańszczyzny, co miało się stać magnesem dla chłopów, którzy dzięki temu mieli przyłączyć się do ruchu. Okazało się to niewystarczające, bowiem animozje pomiędzy jednymi i drugimi przybrały zbyt wielkie rozmiary. Uciskany latami chłop tkwił w nienawiści do dziedzica, który nie zdawał sobie kompletnie sprawy z braku chłopskiej świadomości narodowej. Opowieści o wspólnej walce o niepodległość w żaden sposób nie trafiały do chłopstwa, które pragnęło przede wszystkim lżejszego życia. Wobec rosnącej niechęci suche komunikaty, jakimi próbowano zachęcić włościan (pomimo dobrych intencji szlachcica), nie spotkały się ze zrozumieniem. Oczywiście miały też miejsce próby pracy nad

68 Powstanie krakowskie rozpoczęło się w nocy z 21 na 22 lutego i przetrwało do 3 marca, kiedy to E. Dembowski zginął, idąc na czele procesji do Podgórza. 
świadomością narodową chłopstwa, lecz były prowadzone na niewystarczającą skalę, a na ich efekty trzeba było jeszcze poczekać. W takiej sytuacji zręczna polityka władz austriackich w postaci podburzania włościanina przeciwko ciemiężycielowi, czyli szlachcicowi, oraz obiecanie przywilejów w postaci zniesienia pańszczyzny, co umożliwiłoby raz na zawsze uwolnienie się od pana, przyniosła skutki. Chłop stał się narzędziem w rękach władz - umiejętnie poprowadzony wylał falę gromadzonej przez lata niechęci w postaci ataków na dwory i szlachtę. Ważnym aspektem jest pod tym względem pojęcie świadomości narodowej najniższej warstwy społecznej. Obecnie praktycznie nie dysponujemy stanem wiedzy na jej temat w odniesieniu do I połowy XIX w. Najprawdopodobniej takowa po prostu nie istniała ${ }^{69}$, a wszelkie rozważania to uogólniane ze wszystkich dzielnic stereotypy i mity przenoszone z realiów przełomu XIX i XX w. na I połowę XIX w. ${ }^{70}$ Między innymi kwestię świadomości narodowej poruszył we wspomnianym dziele Turoń Żeromski, opierając się zresztą w znacznej mierze - jak już zostało powiedziane - na Pamiętniku F. Wiesiołowskiego, aktywnego uczestnika wydarzeń stanowiących niejako początek rabacji galicyjskiej. On i jemu podobni zapewne dopiero po analizowanych wydarzeniach zrozumieli popełnione błędy. Absolutnie nie można w związku z tym usprawiedliwiać barbarzyństwa, którego dokonali chłopi, ani przebiegłego planu realizowanego przez władze austriackie. Trzeba jednak przyznać, spoglądając na tę kwestię z nieco innej strony, iż postępowanie żadnej ze stron nie może być ocenione jako jednoznacznie negatywne czy pozytywne. Choć Pamiętnik Wiesiołowskiego jest subiektywną relacją naocznego świadka wydarzeń przede wszystkim z 1846 r., to z pewnością stanowi pozycję istotną do wiedzy na temat przedstawionych wyżej wydarzeń. Jako niezwykle ważna persona $\mathrm{w}$ środowisku spiskowym autor wspomnień ostatecznie zaakceptował decyzję o przyspieszeniu wybuchu powstania. Tym samym miał istotny wpływ na przebieg wiążących się z wcześniejszym terminem jego wybuchu wydarzeń. Błędna byłaby w tej sytuacji ocena, że mogło to w jakikolwiek sposób zaważyć na braku powodzenia ruchu rewolucyjnego z 1846 r. Brak jedności wewnątrz konspiratorów, brak poparcia ze strony magnaterii czy nie najlepsze relacje, a przede wszystkim brak odpowiedniego dialogu z chłopami - to wszystko sprawiało, że szlachta pozbawiona była sojuszniczej klasy społecznej. Sama nie stanowiąc jednolicie działającego organizmu spowodowała chaos organizacyjny,

${ }_{69}$ T. Kargol, Świadomość chłopów w Galicji w pierwszej połowie XIX wieku. Zarys problemu, „Prace Historyczne” 2017, nr 144(2), s. 403; zob. też: P. Ja ku b i e c, „Dwie dusze” - czyli ewolucja tożsamości społecznej i narodowej ludności chłopskiej Galicji w drugiej połowie XIX i na początku XX wieku, „Prace Historyczne” 2017, nr 144(2), s. 413-426.

70 T. Kargol, op. cit. 409. 
co owocowało decyzjami, które trzeba było podejmować na szybko, bez możliwości odpowiedniej analizy sytuacji. W połączeniu z chociażby niezależnym od samych powstańców czynnikiem pogodowym dopełniło to obraz zupełnej klęski, która stanowiła osobistą porażkę uczestników powstania. Dla F. Wiesiołowskiego, niezwykle zaangażowanego w przygotowania, poza wielkim zawodem wydarzenie stanowiło prolog do odejścia od polityki. To sprawiło, że nigdy później nie miał tak wielkiego wpływu na losy dążącego do odzyskania niepodległości narodu jak podczas nieudanego powstania w $1846 \mathrm{r}$.

\section{Bibliografia}

\section{Źródła rękopiśmienne}

Zakład Narodowy im. Ossolińskich we Wrocławiu rkps 2003/I, Żeleńska H., Notatki wypadków niektórych dziejących się w Galicyi od 18 lutego [1]846 roku.

\section{Źródła drukowane}

Dembiński S., Rok 1846. Kronika dworów szlacheckich zebrana na pięćdziesięcioletniq rocznice smutnych wypadków lutego, Jasło 1896.

Limanowski B., Ostatnie lata dziejów powszechnych. Od 1846 r. do dni dzisiejszych, Lwów 1881.

Michna W., Pamiętniki naocznego świadka z roku 1846, „Kalendarz Ilustrowany Wieńca i Pszczółki: pisemek politycznych ludowych na rok pański 1880”.

Ostaszewski-Barański K., Krwawy rok. Opowiadanie historyczne, Złoczów 1897.

Rabacja na Powiślu. Dziennik Marianny Pikuzińskiej i relacje chłopskie o krwawych wydarzeniach 1846 r., oprac. K. Bańburski, W. Konieczny, Tarnów 2006.

Rosnowska J., Dzieje poety. O Wincentym Polu, Warszawa 1973.

Wiesiołowski F., Pamiętnik z r. 1845-46, Lwów 1868.

\section{Opracowania}

Bednarek J., Spory wokół wydarzeń krajowych 1846 roku na łamach prasy Wielkiej Emigracji w latach 1846-1848, Torun 2003.

Dębicki L., Z dawnych wspomnień 1846-1848, Kraków 1903.

Groniowski K., Uwłaszczenie chłopów w Polsce. Geneza, realizacja, skutki, Warszawa 1976.

Kargol T., Świadomość chłopów w Galicji w pierwszej połowie XIX wieku. Zarys problemu, „Prace Historyczne” 2017, nr 144 (2), s. 401-411.

Kieniewicz S., Sanguszko Władysław Hieronim (1803-1870), [w:] Polski słownik biograficzny, t. 34, red. H. Markiewicz, Wrocław-Kraków-Warszawa 1992-1993, s. 514-517.

Kieniewicz S., Ruch chłopski w Galicji w 1846 roku, Wrocław 1951.

Kracik J., W Galicji trzeźwiejącej, krwawej, pobożnej, Kraków 2007.

Limanowski B., Historia ruchu rewolucyjnego w Polsce w 1846 r., Kraków 1913.

Montowski M., Krew, która woła. Pamięć i niepamięć o rzezi galicyjskiej 1846, Kraków 2016.

Poklewska K., Krew na śniegu. Rzecz o rabacji galicyjskiej w literaturze polskiej, Wrocław 1986. 
Rok 1846 w Galicji. Ludzie, wydarzenia, tradycje, oprac. M. Śliwa, Kraków 1997.

Tyrowicz M., Wizerunki sprzed stulecia, Kraków 1968.

Żychowski M., Rok 1846 w Rzeczypospolitej Krakowskiej i Galicji, Warszawa 1956.

\begin{abstract}
The Unsuccessful Lisiogórska Expedition as an Attempt of the Insurrectionary Movement in 1846 on the Territory of the Town of Tarnow and its Surroundings in the Light of Memories of Franciszek Wiesiołowski
\end{abstract}

The article presents events which occurred on Tarnów lands before and during the unsuccessful insurrectionary movement in 1846 - the movement called Krakow Uprising. The article focuses on the fate of the count Franciszek Wiesiołowski who was appointed by the Central Committee in Poznań as the governor of Galicia responsible for the whole military movement on this area. The discussed period includes the time form the first days of February 1846 to 19 February, which means to the day when the independence burst on the Tarnów land was nipped in the bud. The article is mainly based on the diary of Franciszek Wiesiołowski - thanks to his personal account from the period preceding the uprising we get to know in detail the analyzed events, especially the expedition to Lisia Góra which was instantly stopped. This event, and the fact that other troops were dispersed or arrested, contributed to putting an end to the unfinished revolt. It was also the beginning of a short but violent period of chaos called the Galician Slaughter.

\title{
KEYWORDS
}

Kraków Uprising, Galicia, Franciszek Wiesiołowski, Lisia Góra, 1846, Galician Slaughter 